\title{
Water in Descriptions of Global Geoparks: Not Less Important than Geology?
}

\author{
Dmitry A. Ruban ${ }^{1,2}$ \\ 1 K.G. Razumovsky Moscow State University of Technologies and Management (the First Cossack University), \\ Zemlyanoy Val 73, Moscow 109004, Russia; ruban-d@mail.ru \\ 2 Southern Federal University, 23-ja linija Street 43, Rostov-on-Don 344019, Russia
}

Received: 19 August 2019; Accepted: 6 September 2019; Published: 8 September 2019

check for updates

\begin{abstract}
Water is an important landscape element of protected areas, but its significance to geoparks (parks representing geological heritage) is still unclear. The content of the official, standardized descriptions of the UNESCO global geoparks (144 in total) was analyzed in order to understand the consideration of water by geopark creators/managers. It was found that water objects (seas/oceans, rivers, and lakes are most common) are mentioned in 55\% of these descriptions, and $47 \%$ of the latter bear photos of water objects. Moreover, water is generally strongly related to geological heritage (in $80 \%$ of cases). These findings imply a significant attention to hydrodiversity in geoparks (apparently, official descriptions reflect global geopark practice and intentions). This attention does not differ between Europe, Southeast Asia, and Latin America. It has increased in the 2010s relatively to the 2000s. The registered consideration of water in geoparks can be explained differently, and one plausible hypothesis links it to an increasing willingness of geopark creators/managers to demonstrate the natural integrity of geological heritage landscapes. Such attention to water is suitable to deliver the knowledge of this integrity to tourists, but it increases the risks of visitor distraction from geological heritage, shifting to easy-to-understand and beautiful water objects.
\end{abstract}

Keywords: aesthetic attractiveness; aquatic landscape; conservation; hydrodiversity; natural heritage; tourism; water management

\section{Introduction}

In many protected areas such as national parks and biosphere reserves, water objects are of special importance. On the one hand, they sustain unique ecosystems that require conservation [1,2] and on the other hand, they add aesthetic value to landscapes attracting visitors and, thus, facilitating tourism [3]. Moreover, water resources are essential to the functioning of protected areas [4-6]. This evidence is related to traditional, 'all-inclusive' protected areas aimed at conservation and recreational use of landscapes and ecosystems. A new type of nature-based establishment has appeared recently, namely the geopark. Geoparks are areas of different size (from very small to almost country-scale) bearing unique geological features (geological heritage) that need efficient conservation and permitting development of scientific, educational, and tourism activities. The idea of geoparks is explained, particularly, in the works of Farsani et al. [7,8] Henriques and Brilha [9], Jones [10], Lazzari and Aloia [11], Mc Keever and Zouros [12], Nikolova and Sinnyovsky [13], Ruban [14], Ruban and Yashalova [15], and Stoffelen [16]. Geoparks are not protected areas sensu stricto because geological heritage serves more to exploitation than to conservation there, however balancing these activities and the contribution to local sustainable development are cornerstones of each geopark. Thus, many (if not all) geoparks can be considered as protected areas de facto. 
The most important geoparks representing geological features of global uniqueness are members of the UNESCO Global Geoparks network, which includes about 150 geoparks in dozens of countries and is continuing to gain importance. The international growth of the geopark movement has posed new questions. First, geoparks often occupy territories where non-geological elements of nature (soils, water bodies, endangered species, ecosystems, etc.) also occur, and these are very often of heritage value. On the one hand, their consideration is necessary to diversify conservation and recreation activities in geoparks while on the other hand, these 'auxiliary' natural elements have to be protected from excessive exploitation of geological heritage resource. For instance, water resources have become the subject of analysis in the Langkawi geopark in Malaysia [17], the Majella geopark in Italy [18], and the Luoping Biota geopark in China [19]. More generally, it is possible to state that geoparks represent geological heritage landscapes (sensu [20]), i.e., landscapes dominated by unique geological features, but not restricted to them. Undoubtedly, water is a very important element of geopark landscapes, and the societal impact of these establishments (Figure 1) can be also referred to it. Geoparks are essentially social projects linked to sustainable development, and water is a vital resource of the latter. Tourist activities in geoparks may lead to significant depletion or pollution of water. Finally, water can be related to geology directly (e.g., river incision with canyon formation, tufa deposits of waterfalls, salt deposition in hyper-saline lakes, etc.).

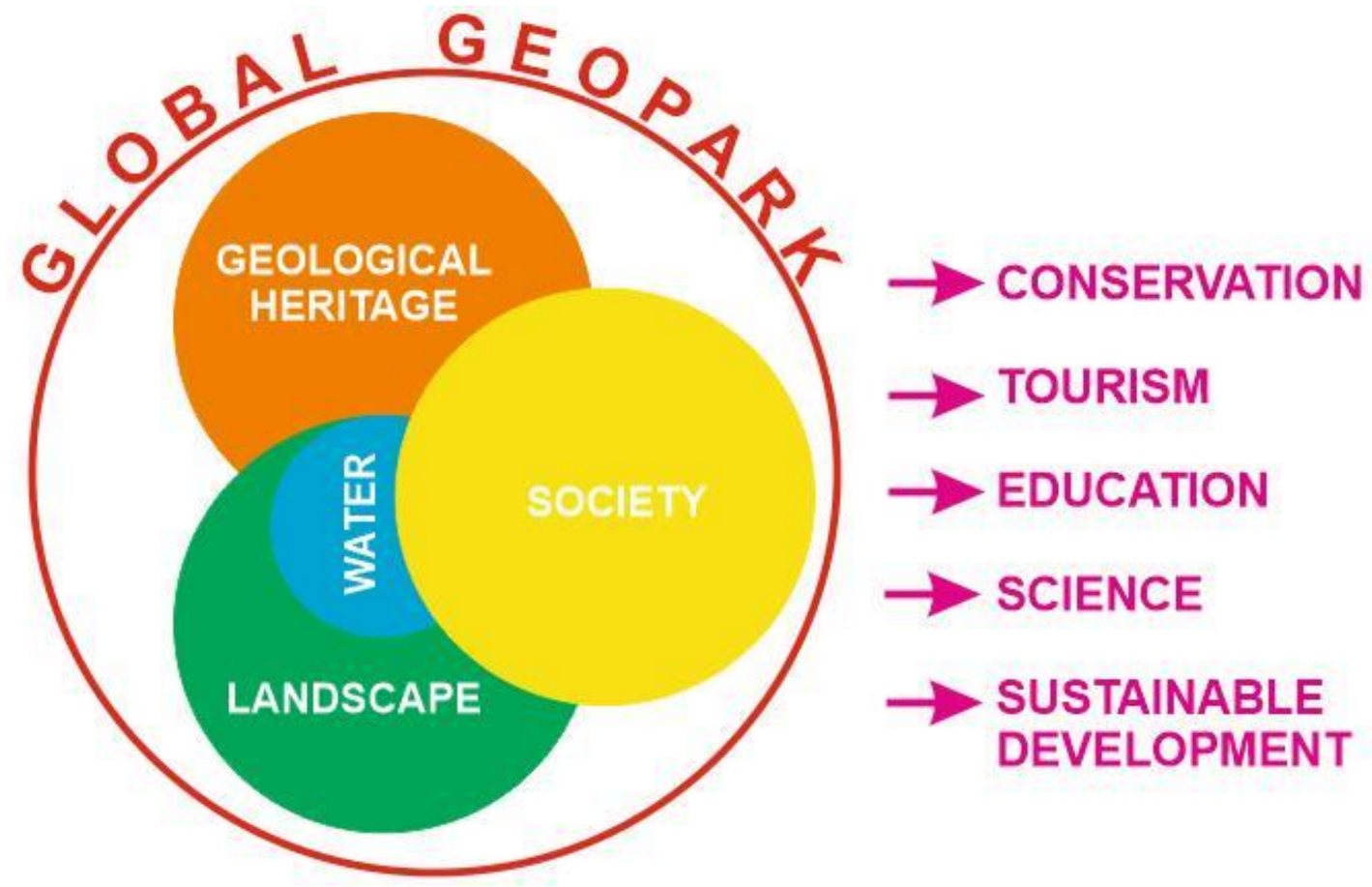

Figure 1. The relevance of water to the global geopark essence.

The role of water in geoparks has been considered occasionally in previous works (e.g., [17-19]), but evidence is scarce, often local, and remains dispersed in the literature. Undoubtedly, the noted issue is very important and needs careful investigation. The objective of the present paper is to provide the first analysis of water consideration in official descriptions of all UNESCO global geoparks. The other geopark networks (e.g., the European network) and lower-status geoparks (e.g., national) are not considered because of limited and often incomplete knowledge of them. In this study, attention is paid to how water is treated by geopark creators/managers. Indeed, water bodies can be found in many such establishments and their importance is indisputable, but it is of crucial importance to understand how significant these are thought to be. In other words, this study focuses on managerial opinions, which may or may not reflect the true relevance of water to geological heritage. 


\section{Materials and Methods}

The object of analysis is the entity of official descriptions of the UNESCO global geoparks [21]. These descriptions are generally standardized and reflect the state of a given geopark, its main geological and other natural features, and societal context. Their utility to various analyses has been proven by previous studies [14,15]. Particularly, such descriptions permit the understanding of how geopark resources and peculiarities are treated by their creators/managers, how these are ranked, and how these are promoted. In other words, these descriptions clarify the concept of each given geopark, its functioning, and intentions. For instance, if water is included in such a description, this means that its relevance to the geopark purpose is well-understood and well-accepted. Undoubtedly, not in all cases is water thought to be so important if even available and unique. It should be added that the presence of water can be guessed on the basis of a given official geopark description (e.g., when island is mentioned). However, this is impossible in some cases, and, thus, to avoid biased interpretation of the water landscape, only direct consideration of water objects is taken into account. Missing any important information is recompensed significantly by the above-mentioned analysis of photos. For instance, sea is often well-visible on photos in the case of islands, and, thus, water objects are considered anyway.

This study is based on the content analysis of the official global geopark descriptions. Each geopark description is checked in order to find the information about water objects (= water bodies). Although such objects often overlap with geomorphological features, the latter are understood as landforms and not considered in the present analysis. The very presence of water itself is registered. For instance, if the word "river" or "lake" is found in the description, this means it is considered a water object. Three main, objective parameters are recorded, namely type of water objects (seas, rivers, lakes, waterfalls, etc.), relevance of these objects to geological heritage (Table 1), and presence of water objects on photos included in descriptions (some descriptions are provided without photos). This information is then summarized. The type of water objects can be easily detected by words used in the description. Fortunately, complexities of water body definitions do not affect the available descriptions. This means their authors (presumably, geopark representatives) write about rivers, lakes, springs, etc. naming these hydrological phenomena simply and correctly. However, water objects are not specified in some cases, therefore, types cannot be established. To interpret the relevance of water objects to geological heritage, the general context of use of water-related words in phrases is analyzed by simple templates provided in Table 1. Finally, visibility of water on photos that accompany many descriptions is a condition by which to judge these photos relevant to water consideration in a given geopark description.

In the present study, only water objects of the geological present are analyzed, not ancient bodies (palaeoriver, palaeolakes, etc.) interpreted for the geological past and belonging directly to geological heritage. Attention is paid to water in only the liquid state (including hot water in springs and geothermal fields), i.e., glaciers and snowfields are not analyzed; these constitute the other natural elements of geological heritage landscapes and deserve separate discussion. Moreover, frozen water is tied stronger to geological environment than liquid water, and, thus, the relevant objects can be directly related to geological heritage.

The information gathered this way is further compiled to form a kind of database that can be analyzed quantitatively. First, the number of global geoparks with official descriptions mentioning water objects and/or photos representing them is measured. Second, the relative frequency of consideration of the principal water objects is established. The types of water objects are detected on the basis of the compiled information. Third, the preferred relevance of water to geological heritage is established. Fourth, possible differences in water consideration between geoparks of the principal regions of the world are traced. Currently, global geoparks are concentrated in Europe, Southeast Asia, and Latin America, and these are the principal regions. Fifth, changes in the attention to water in global geoparks through time are established. For this purpose, the year of the first geopark designation is considered, although this information is rather heterogeneous in the available descriptions, and the relevant interpretations should be carried out with a certain caution. 
Table 1. Gradation of the relevance of water objects to geological heritage in the official descriptions of the UNESCO global geoparks (proposed by the author).

\begin{tabular}{|c|c|c|}
\hline Relevance & Explanation & Examples of Phrasing in Geopark Description \\
\hline Low & $\begin{array}{l}\text { Co-occurrence with unique } \\
\text { geological phenomena }\end{array}$ & $\begin{array}{c}\text { 1. Besides geological heritage features such as rare } \\
\text { minerals and fossils, this geopark also hosts spectacular } \\
\text { waterfalls and lakes. } \\
\text { 2. The geological heritage includes stratotypes of } \\
\text { Cretaceous units and folded rocks. A river crosses the } \\
\text { territory of this geopark. }\end{array}$ \\
\hline Medium & $\begin{array}{l}\text { Unique geological phenomena } \\
\text { linked to water activity }\end{array}$ & $\begin{array}{l}\text { 1. The geopark's geological heritage includes Triassic } \\
\text { reefs and deep gorges cut by rivers. } \\
\text { 2. Unique Devonian rock exposures are available along } \\
\text { the coast because of marine abrasion. }\end{array}$ \\
\hline High & $\begin{array}{l}\text { Water objects as unique geological } \\
\text { phenomena }\end{array}$ & $\begin{array}{l}\text { 1. The geological heritage of this geopark consists of } \\
\text { igneous rocks, impact crater, and two hyper-saline lakes. } \\
\text { 2. Waterfalls, carbonate mounds, and ancient volcano } \\
\text { edifices are unique geological features of this geopark. }\end{array}$ \\
\hline
\end{tabular}

Note: the examples are not extracts from the real descriptions of the UNESCO global geoparks, and they are proposed to illustrate phrasing typical for detection of each type of the relevance.

\section{Results}

Water objects are considered in the official descriptions of many UNSECO global geoparks, although the context of this consideration differs (Table 2). From a total of 144 available descriptions, 79 deal with water (55\%) and 67 contain photos representing water objects (47\%). Most frequently, consideration of rivers, sea/oceans, and lakes is found (Figure 2). Less attention is paid to springs and waterfalls, which is strange because these objects are not only aesthetically attractive, but also tied closely to unique geological processes. Anyway, the official descriptions of the UNESCO global geoparks reflect hydrodiversity very well. Another notable peculiarity of many descriptions is consideration of water objects not as a separate, hydrological category, but among geomorphological features. This seems to be unusual as if to restrict geomorphological features to landforms. Interestingly, some descriptions accompanied with photos of water objects do not mention these in the text, and the shown water objects seem to be more impressive than the promoted geological features. This means such photos have been chosen chiefly out of 'purely' aesthetic reasons; these often represent spectacular coastlines, lakes, and waterfalls.

Table 2. Water objects considered as elements of the UNESCO global geoparks (state for August 2019; interpretation by the author on the basis of the official geopark descriptions [21]).

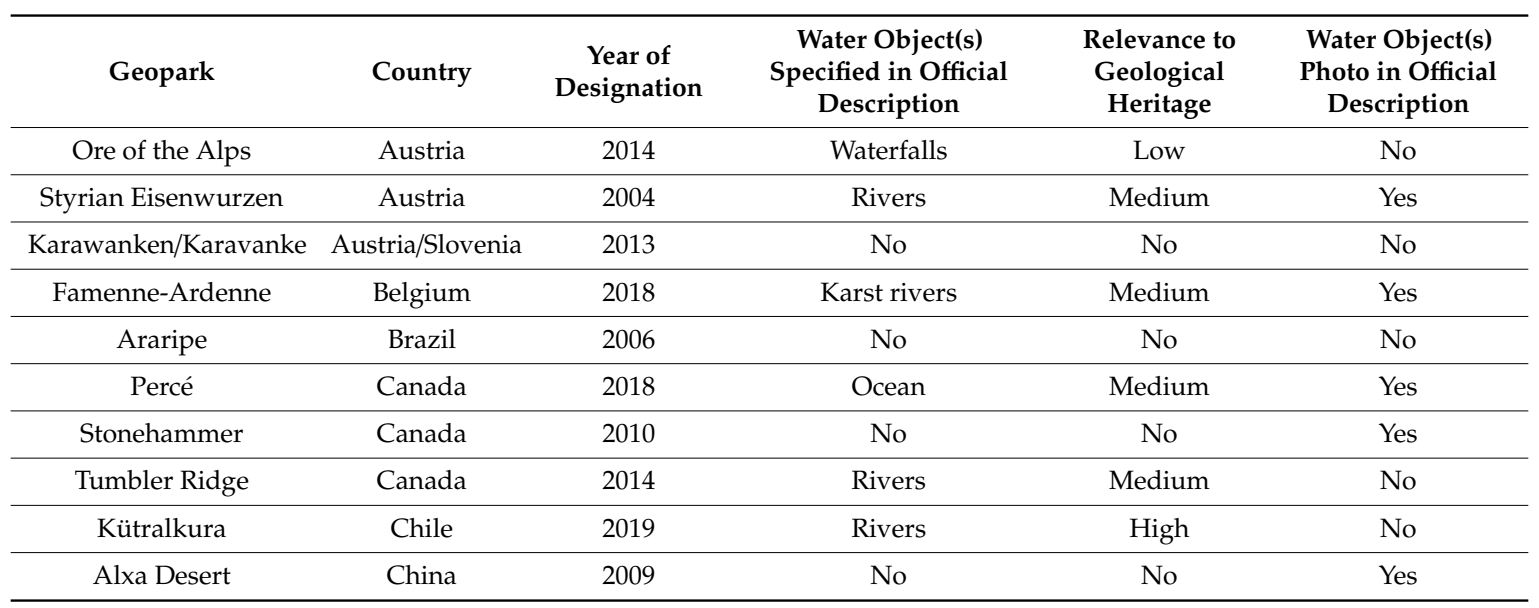


Table 2. Cont.

\begin{tabular}{|c|c|c|c|c|c|}
\hline Geopark & Country & $\begin{array}{c}\text { Year of } \\
\text { Designation }\end{array}$ & $\begin{array}{c}\text { Water Object(s) } \\
\text { Specified in Official } \\
\text { Description }\end{array}$ & $\begin{array}{l}\text { Relevance to } \\
\text { Geological } \\
\text { Heritage }\end{array}$ & $\begin{array}{c}\text { Water Object(s) } \\
\text { Photo in Official } \\
\text { Description }\end{array}$ \\
\hline Arxan & China & 2017 & $\begin{array}{l}\text { Hot springs, crater lakes, } \\
\text { rivers }\end{array}$ & High & Yes \\
\hline Dali-Cangshan & China & 2014 & No & No & No \\
\hline Danxiashan & China & 2004 & Rivers & Low & Yes \\
\hline Dunhuang & China & 2015 & No & No & No \\
\hline Fangshan & China & 2006 & No & No & Yes \\
\hline Funiushan & China & 2006 & No & No & No \\
\hline Guangwushan-Nuoshuihe & China & 2018 & No & No & Yes \\
\hline Hexigten & China & 2005 & No & No & No \\
\hline Hong Kong & China & 2011 & Sea & Low & Yes \\
\hline Huanggang Dabieshan & China & 2018 & No & No & No \\
\hline Huangshan & China & 2004 & Not specified & Low & No \\
\hline Jingpohu & China & 2006 & Lakes & High & Yes \\
\hline Jiuhuashan & China & 2019 & Not specified & High & No \\
\hline Keketuohai & China & 2017 & No & No & No \\
\hline Leiqiong & China & 2006 & Maar lakes, sea & High & Yes \\
\hline Leye Fengshan & China & 2010 & Karst rivers and springs & High & Yes \\
\hline Longhushan & China & 2008 & Rivers & Low & Yes \\
\hline Lushan & China & 2004 & Rivers, lake & Low & Yes \\
\hline Mount Kunlun & China & 2014 & No & No & No \\
\hline Ningde & China & 2010 & River & Medium & Yes \\
\hline Qinling Zhongnanshan & China & 2009 & Not specified & Low & No \\
\hline Sanqingshan & China & 2012 & No & No & No \\
\hline Shennongjia & China & 2013 & No & No & No \\
\hline Shilin & China & 2004 & No & No & Yes \\
\hline Songshan & China & 2004 & No & No & No \\
\hline Taining & China & 2005 & No & No & Yes \\
\hline Taishan & China & 2006 & No & No & No \\
\hline Tianzhushan & China & 2011 & No & No & No \\
\hline Wangwushan-Daimeishan & China & 2006 & River & Medium & No \\
\hline Wudalianchi & China & 2004 & Cold mineral springs & High & No \\
\hline Xingwen & China & \multicolumn{4}{|c|}{ Official description not accessible } \\
\hline Yandangshan & China & 2005 & Sea, waterfalls & High & No \\
\hline Yanqing & China & 2013 & No & No & No \\
\hline Yimengshan & China & 2019 & No & No & Yes \\
\hline Yuntaishan & China & 2004 & Rivers & High & Yes \\
\hline Zhangjiajie & China & 2004 & Not specified & High & No \\
\hline Zhijindong Cave & China & 2015 & River, lake & High & No \\
\hline Zigong & China & 2008 & No & No & No \\
\hline Papuk & Croatia & 2007 & Karst springs & High & Yes \\
\hline Vis Archipelago & Croatia & 2019 & Sea & Medium & Yes \\
\hline Troodos & Cyprus & 2015 & No & No & No \\
\hline Bohemian Paradise & Czechia & 2005 & No & No & No \\
\hline Odsherred & Denmark & 2014 & Sea & Medium & Yes \\
\hline Imbabura & Ecuador & 2019 & $\begin{array}{l}\text { Lakes, waterfalls, hot } \\
\text { springs }\end{array}$ & High & Yes \\
\hline
\end{tabular}


Table 2. Cont.

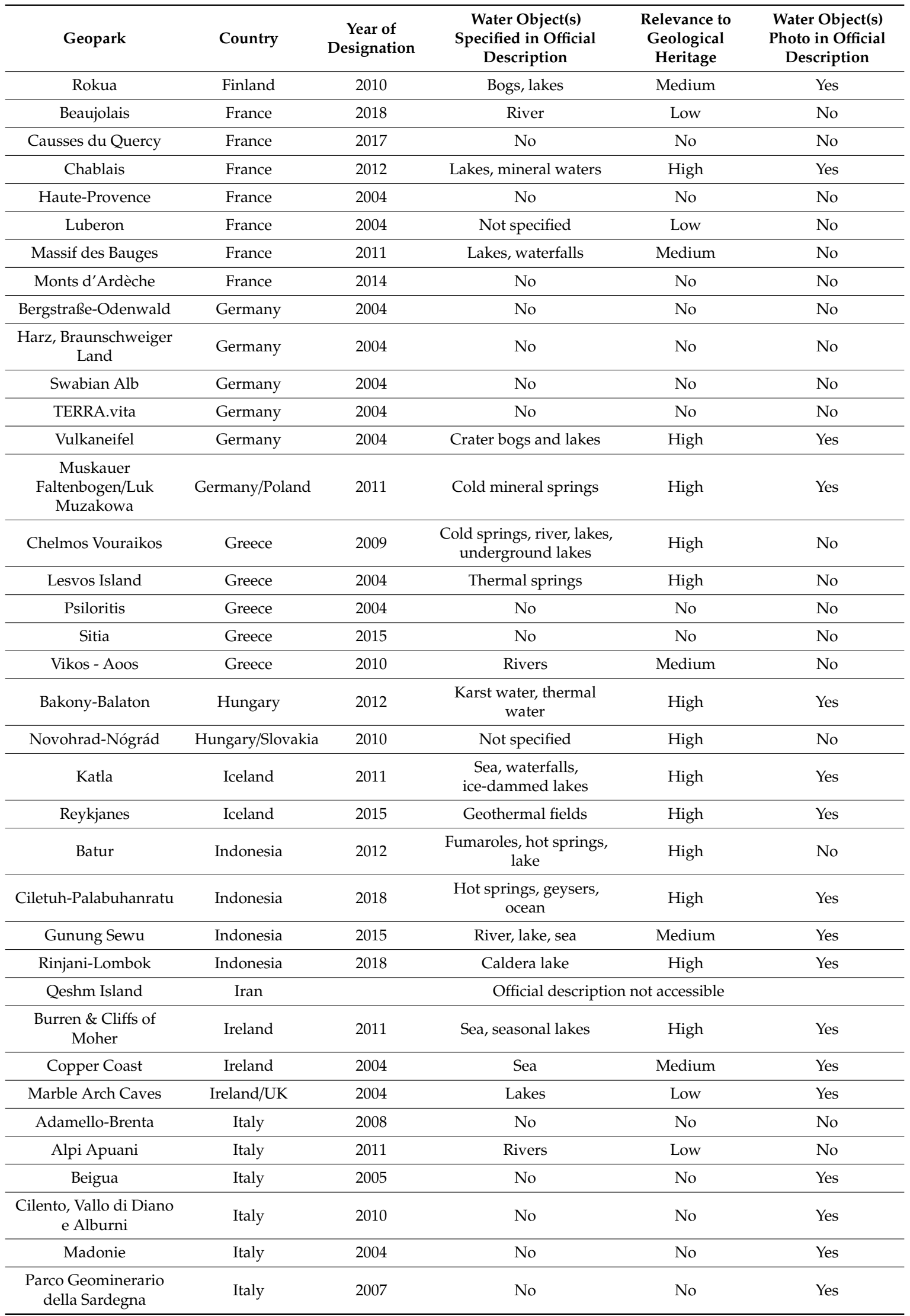


Table 2. Cont.

\begin{tabular}{|c|c|c|c|c|c|}
\hline Geopark & Country & $\begin{array}{c}\text { Year of } \\
\text { Designation }\end{array}$ & $\begin{array}{c}\text { Water Object(s) } \\
\text { Specified in Official } \\
\text { Description }\end{array}$ & $\begin{array}{l}\text { Relevance to } \\
\text { Geological } \\
\text { Heritage }\end{array}$ & $\begin{array}{c}\text { Water Object(s) } \\
\text { Photo in Official } \\
\text { Description }\end{array}$ \\
\hline Pollino & Italy & 2015 & No & No & No \\
\hline Sesia Val Grande & Italy & 2013 & No & No & No \\
\hline Rocca di Cerere & Italy & 2004 & Not specified & Low & No \\
\hline Tuscan Mining Park & Italy & 2010 & No & No & Yes \\
\hline Aso & Japan & 2014 & No & No & No \\
\hline Itoigawa & Japan & 2009 & No & No & Yes \\
\hline Izu Peninsula & Japan & 2018 & Hot springs & High & Yes \\
\hline Mt. Apoi & Japan & 2015 & No & No & Yes \\
\hline Muroto & Japan & 2011 & Sea & Medium & Yes \\
\hline Oki Islands & Japan & 2013 & Sea & Medium & Yes \\
\hline San'in Kaigan & Japan & 2010 & No & No & No \\
\hline Toya-Usu & Japan & 2009 & $\begin{array}{l}\text { Not specified, hot } \\
\text { springs }\end{array}$ & Low & Yes \\
\hline Unzen Volcanic Area & Japan & 2009 & No & No & Yes \\
\hline Langkawi & Malaysia & 2007 & Sea, rivers & Low & Yes \\
\hline Comarca Minera & Mexico & \multicolumn{4}{|c|}{ Official description not accessible } \\
\hline Mixteca Alta & Mexico & 2017 & No & No & No \\
\hline M'Goun & Morocco & 2014 & No & No & No \\
\hline De Hondsrug & Netherlands & 2013 & No & No & No \\
\hline Gea Norvegica & Norway & 2006 & No & No & Yes \\
\hline Magma & Norway & 2006 & No & No & Yes \\
\hline Trollfjell & Norway & 2019 & Sea & Low & Yes \\
\hline $\begin{array}{c}\text { Colca y Volcanes de } \\
\text { Andagua }\end{array}$ & Peru & 2019 & No & No & No \\
\hline Açores & Portugal & 2013 & $\begin{array}{l}\text { Offshore hydrothermal } \\
\text { fields }\end{array}$ & High & No \\
\hline Arouca & Portugal & 2009 & No & No & No \\
\hline $\begin{array}{l}\text { Naturtejo da Meseta } \\
\text { Meridional }\end{array}$ & Portugal & 2006 & No & No & No \\
\hline Terras de Cavaleiros & Portugal & 2014 & Rivers, artificial lake & Low & Yes \\
\hline Hateg & Romania & 2005 & No & No & Yes \\
\hline Cheongsong & South Korea & 2017 & Mineral spring & High & Yes \\
\hline Jeju Island & South Korea & 2010 & No & No & No \\
\hline Mudeungsan & South Korea & 2018 & Waterfalls & High & No \\
\hline Idrija & Slovenia & 2013 & Not specified & Low & No \\
\hline Basque Coast & Spain & 2010 & Sea & Low & Yes \\
\hline Cabo de Gata-Nijar & Spain & 2006 & Sea & Medium & Yes \\
\hline Central Catalonia & Spain & 2012 & No & No & No \\
\hline $\begin{array}{c}\text { Conca de } \\
\text { Tremp-Montsec }\end{array}$ & Spain & 2018 & No & No & No \\
\hline Courel Mountains & Spain & 2019 & Rivers & Medium & Yes \\
\hline El Hierro & Spain & 2014 & Sea & Low & Yes \\
\hline $\begin{array}{l}\text { Lanzarote and Chinijo } \\
\text { Islands }\end{array}$ & Spain & 2015 & Not specified & Low & Yes \\
\hline Las Loras & Spain & 2017 & Rivers & Medium & No \\
\hline
\end{tabular}


Table 2. Cont

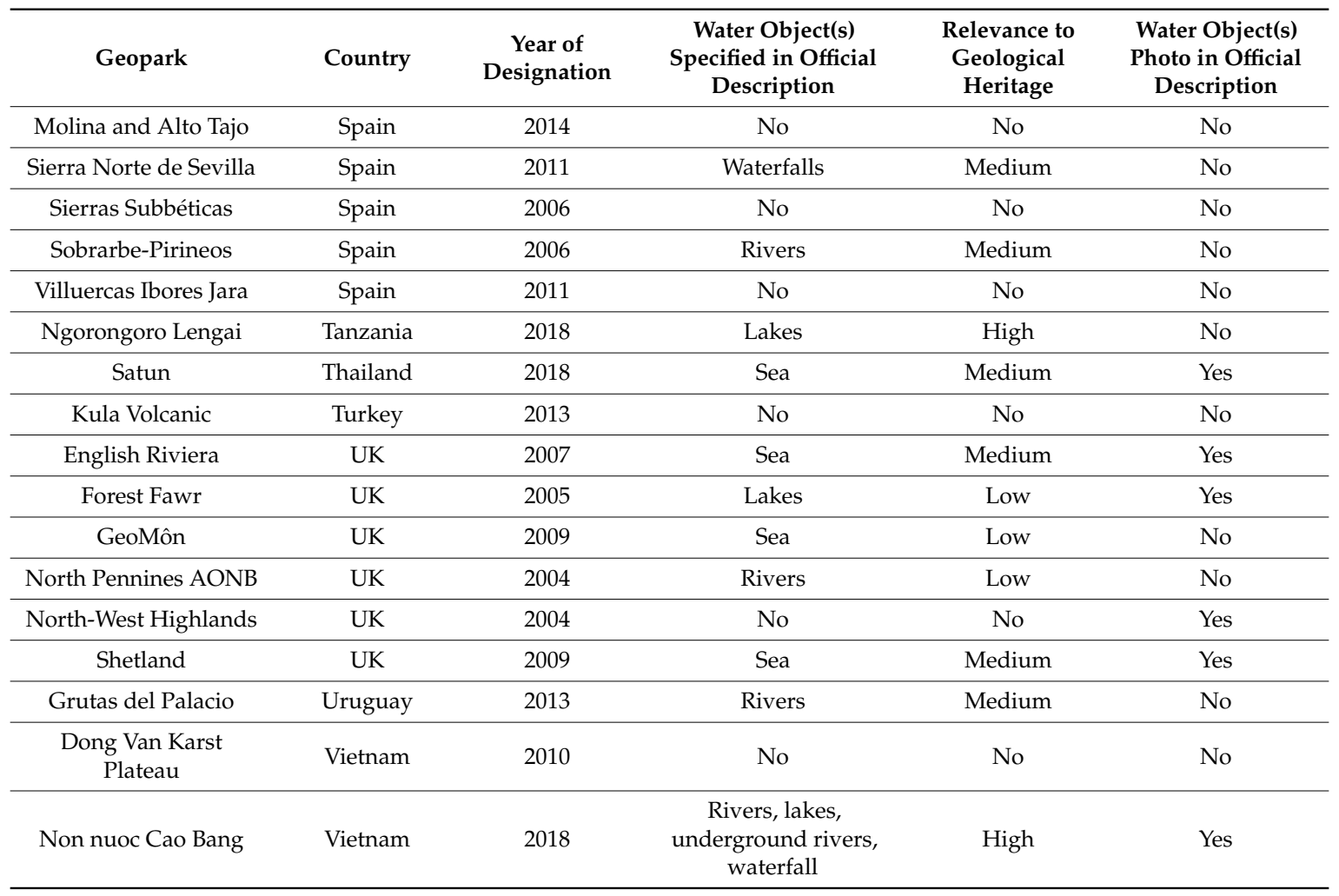

\section{SEA / OCEAN}

RIVER

LAKE

WATERFALL

SPRING
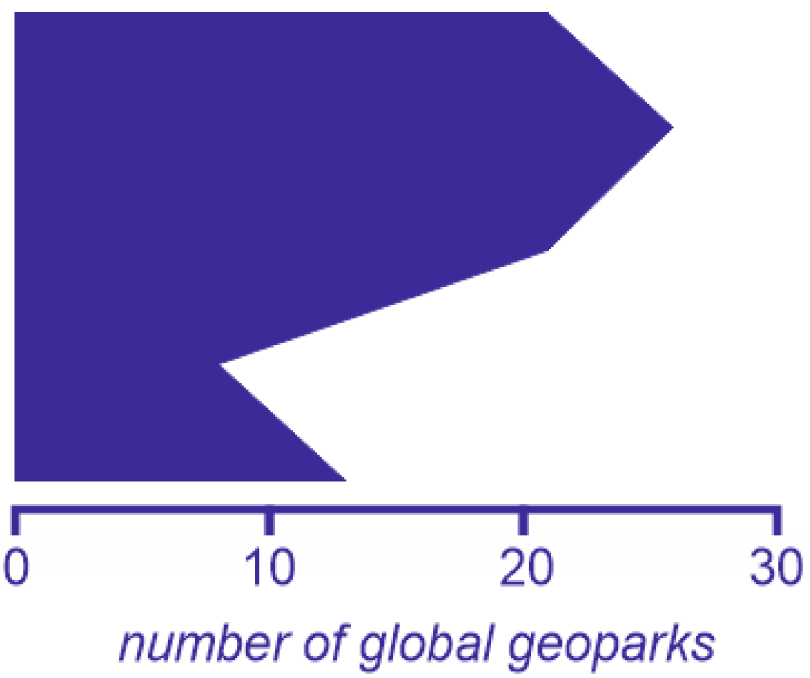

Figure 2. Principal water objects considered in the official descriptions of the global geoparks.

In $41 \%$ of cases, the relevance of water to geological heritage is high, i.e., water objects are thought to be constituents of the geological heritage itself. The medium and low relevance is less significant (39\% and 29\%, respectively). This means that the global geopark creators/managers tend to consider water in geoparks seriously, i.e., without detachment from geologically unique features (the coupled high and medium relevance constitutes $80 \%$ of cases). However, an alternative explanation is also possible: geopark managers/creators do not pay attention (or do not have experience) to separate geological and non-geological landscape elements and tend to label many of them as 'geological' without the necessary care. 
The geographical distribution of global geoparks with official descriptions considering water objects does not show any differentiation (Figure 3). In Europe, the number of such geoparks reaches $57 \%$, and the values in Southeast Asia and Latin America are 53\% and 50\%, respectively. This means the differences between major traditions of geopark establishment (apparently, more attention is paid to geology in Europe and more attention is paid to natural context of geological phenomena in Southeast Asia) do not affect consideration of water. There is a weak, but well-visible temporal trend of increase in water consideration. For geoparks designated before 2011, water objects are considered in $50 \%$ of cases, but this value rises to $60 \%$ for geoparks designated later. This implies a certain increase in attention to non-geological elements of geoparks and their relation to geological heritage.

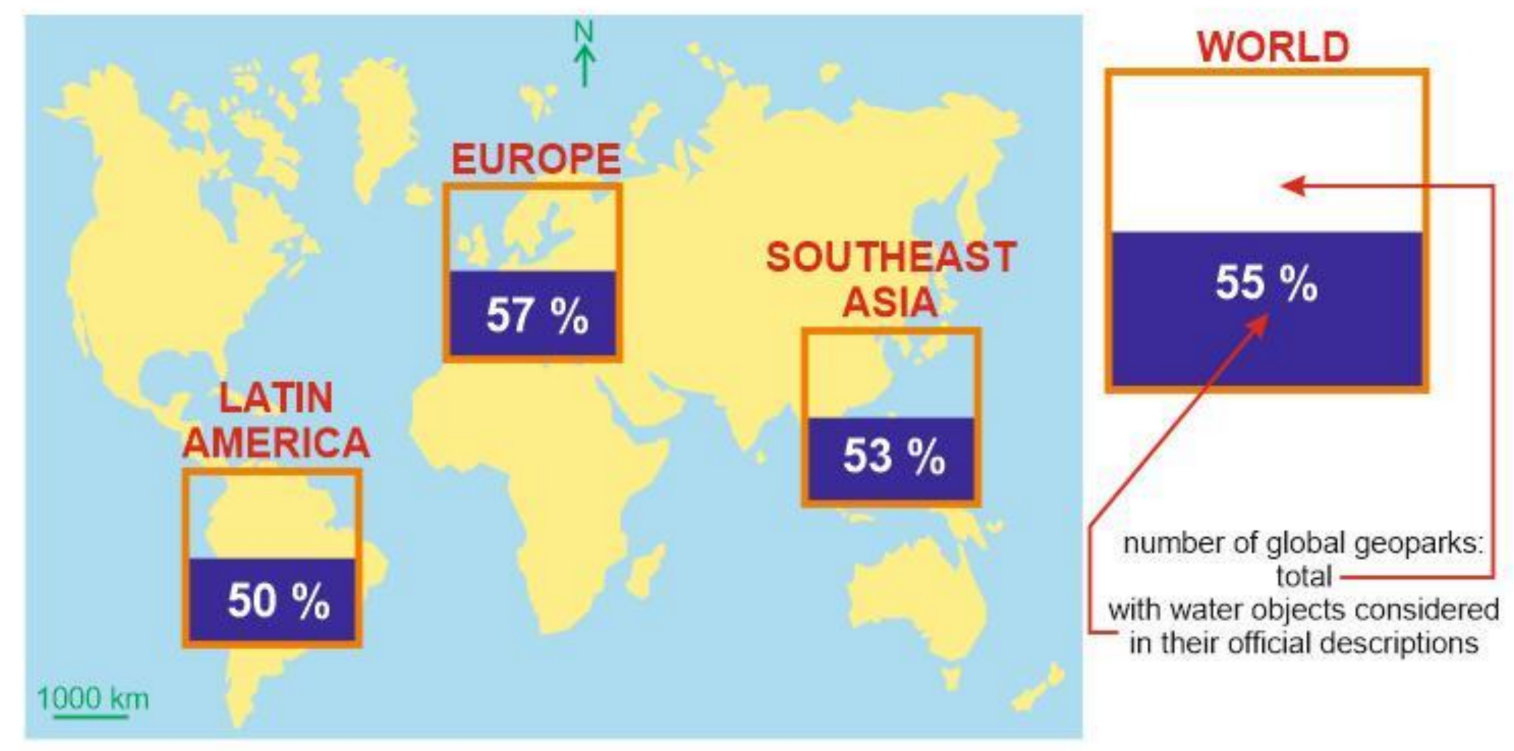

Figure 3. Water objects considered in the official descriptions of the global geoparks in the principal regions.

\section{Discussion and Conclusions}

The results of the undertaken analysis imply that water objects are important natural elements of the UNESCO global geoparks, as one can judge on the basis of their official descriptions (and these objects may be even more important if considering hydrodiversity which is not mentioned in the official descriptions). Moreover, water is closely associated with unique geological phenomena. In other words, water objects are thought to be among the very important constituents of geological heritage landscapes. It is possible to propose three hypotheses to explain this observation. First, water objects are too numerous in territories where geoparks have been created and the geological activity of seas, rivers, and lakes is too intense there, making it impossible to ignore these objects. Second, water is in focus because it adds aesthetic value to landscape which is important to both geopark creators/managers and geopark visitors. Third, attempts to demonstrate the natural integrity of geoparks results in the search for non-geological natural elements, and water bodies are among the best candidates. Most probable, all these hypotheses are plausible in different cases. However, the strengthened emphasis on geodiversity and geological heritage landscape integrity [22-24] and, particularly, links between water and geology in landscape systems [25-27] stimulate geopark practitioners to focus on water bodies. If so, the third hypothesis may provide a kind of universal explanation. This hypothesis is also proved by some results of the present study, i.e., by the absence of geographical differentiation in water consideration (Figure 3) and the increase in this consideration over time (see above). However, the registered consideration of water objects is somewhat haphazard, which is expected as geoparks are essentially aimed more at geology than the rest of nature. 
The main outcome of this study, i.e., the signification attention to water objects in the UNESCO Global Geoparks network, requires discussion of the advantages and disadvantages of the situation where this attention affects geopark management. The advantage is evident: global geoparks contribute to the understanding of nature integrity (Figure 1). This is necessary owing to two circumstances. First, an emphasis on only geology would limit comprehension of the relevance of old rocks and fossils to the modern world. Second, such an emphasis would make the knowledge available in geoparks too specific to attract enough visitors (motivation is a significant challenge in geotourism [28]). However, there is also a serious disadvantage, which is as follows. The majority of tourists, including geotourists (except for relatively rare geoscience professionals, students, and amateurs) do not have enough geological knowledge, and they have been not trained for perception of geological features that are masked by other landscape elements and often need special interpretation [29-32]. In contrast, tourists do not need any special knowledge to judge on rivers, lakes, or waterfalls, and the natural beauty of water objects is a significant attractor of visitors [33-35]. In such a case, co-management of 'purely' geological and hydrological features and their co-promotion through web-pages, brochures, panels, etc. complicates the attraction to geological heritage in geoparks. In other words, geoparks become more natural than geological. This problem becomes even bigger when water is considered in a haphazard manner as occurs in the official descriptions of the global geoparks, especially on photos included in these descriptions. The resulting effect is distraction from geology, which contradicts the very purpose of geoparks aimed essentially at geological heritage.

Regarding the above-said, it is impossible to recommend geopark practice for either full-scale consideration of water objects or total rejection of non-geological landscape elements. Individual solutions should be found in each given case. For instance, water objects can be promoted in-situ, but not advertised ex-situ or their strong links to geological heritage should be emphasized. However, it is worth noting that attempts to reflect nature integrity in such highly specific establishments as geoparks can be both successful and risky. It is also important to consider the uniqueness, i.e., heritage value of geological and water objects on the areas where geoparks are planned. Water heritage is an important topic of modern research [36,37]. Where water objects are more valuable than geological features, it is questionable how reasonable is geopark creation. If hydrological and geological features are of comparable uniqueness, another kind of protected area can be proposed.

The results of the present analysis of water consideration in the official descriptions of the UNESCO global geoparks, i.e., the content analysis of the fixed managerial opinions, enable three principal conclusions to be drawn. First, geopark creators/managers pay significant attention to water and tend to relate it to geological heritage. Second, this attention does not differ geographically on the global scale, but increases over time. Third, the registered situation has advantage and disadvantage, and geopark practitioners should think deeply how to deal with water in order to demonstrate nature integrity and to avoid distraction of visitors from geological heritage. The present study provides a pilot frame of judgments. Further investigations should provide a deeper understanding of the problem. For instance, geopark creators/managers could be interviewed in order to understand their attitudes toward aquatic heritage and water management.

Funding: This research received no external funding.

Acknowledgments: The author gratefully thanks the journal editors and the anonymous reviewers for thorough examination of this paper and helpful suggestions, as well as M.H. Henriques (Portugal) for literature support.

Conflicts of Interest: The author declares no conflict of interest.

\section{References}

1. Azevedo-Santos, V.M.; Frederico, R.G.; Fagundes, C.K.; Pompeu, P.S.; Pelicice, F.M.; Padial, A.A.; Nogueira, M.G.; Fearnside, P.M.; Lima, L.B.; Daga, V.S.; et al. Protected areas: A focus on Brazilian freshwater biodiversity. Divers. Distrib. 2019, 25, 442-448. [CrossRef] 
2. Shaltout, K.; El-Bana, M.; Galal, T. Coastal Lakes as Hot Spots for Plant Diversity in Egypt. Handb. Environ. Chem. 2019, 72, 129-146.

3. De Vos, A.; Cumming, G.S.; Moore, C.A.; Maciejewski, K.; Duckworth, G. The relevance of spatial variation in ecotourism attributes for the economic sustainability of protected areas. Ecosphere 2016, 7, 1207. [CrossRef]

4. Brill, G.; Anderson, P.; O'Farrell, P. Urban national parks in the global South: Linking management perceptions, policies and practices to water-related ecosystem services. Ecosys. Serv. 2017, 28, 185-195. [CrossRef]

5. Morrison-Saunders, A.; Hughes, M.; Pope, J.; Douglas, A.; Wessels, J.-A. Understanding visitor expectations for responsible tourism in an iconic national park: differences between local and international visitors. J. Ecotour. 2019, 18, 284-294. [CrossRef]

6. Thoma, D.P.; Munson, S.M.; Witwicki, D.L. Landscape pivot points and responses to water balance in national parks of the southwest US. J. Appl. Ecol. 2019, 56, 157-167. [CrossRef]

7. Farsani, N.T.; Coelho, C.; Costa, C. Geotourism and geoparks as novel strategies for socio-economic development in rural areas. Int. J. Tour. Res. 2011, 13, 68-81. [CrossRef]

8. Farsani, N.T.; Coelho, C.O.A.; Costa, C.M.M.; Amrikazemi, A. Geo-knowledge Management and Geoconservation via Geoparks and Geotourism. Geoheritage 2014, 6, 185-192. [CrossRef]

9. Henriques, M.H.; Brilha, J. UNESCO Global Geoparks: a strategy towards global understanding and sustainability. Episodes 2017, 40, 349-355. [CrossRef]

10. Jones, C. History of Geoparks. Geol. Soc. Spec. Publ. 2008, 300, 273-277. [CrossRef]

11. Lazzari, M.; Aloia, A. Geoparks, geoheritage and geotourism: Opportunities and tools in sustainable development of the territory. Geoj. Tour. Geosites 2014, 13, 8-9.

12. Mc Keever, P.J.; Zouros, N. Geoparks: Celebrating earth heritage, sustaining local communities. Episodes 2005, 28, 274-278.

13. Nikolova, V.; Sinnyovsky, D. Geoparks in the legal framework of the EU countries. Tour. Manag. Perspect. 2019, 29, 141-147. [CrossRef]

14. Ruban, D.A. Geodiversity as a precious national resource: A note on the role of geoparks. Resour. Policy 2017, 53, 103-108. [CrossRef]

15. Ruban, D.A.; Yashalova, N.N. Geodiversity meanings in global geoparks: an empirical study. Environ. Earth Sci. 2018, 77, 771. [CrossRef]

16. Stoffelen, A.; Groote, P.; Meijles, E.; Weitkamp, G. Geoparks and territorial identity: A study of the spatial affinity of inhabitants with UNESCO Geopark De Hondsrug, The Netherlands. Appl. Geogr. 2019, 106, 1-10. [CrossRef]

17. Mokhtar, M.; Tajam, J.; Wagiman, S. Determination of the sediment contamination level in dangli waters of Langkawi UNESCO Global Geopark, Kedah, Malaysia. Sains Malays. 2019, 48, 45-59. [CrossRef]

18. Liberatoscioli, E.; Boscaino, G.; Agostini, S.; Garzarella, A.; Scandone, E. The Majella National Park: An aspiring UNESCO geopark. Geosciences 2018, 8, 256. [CrossRef]

19. Xie, T.; Gan, Y.-L.; Zhang, Q.-Y.; Hu, S.-X.; Zhou, C.-Y.; Huang, J.-Y.; Wen, W.; Yang, W.-L.; Zhu, G.-Y. Geoheritage evaluation of the Luoping Biota National Geopark in Yunnan Province. Geology 2013, 40, 1959-1967. (In Chinese)

20. Ruban, D.A. Aesthetic properties of geological heritage landscapes: Evidence from the Lagonaki Highland (Western Caucasus, Russia). J. Geog. Inst. "Jovan Cvijić" SASA 2018, 68, 289-296. [CrossRef]

21. List of UNESCO Global Geoparks (UGGp). Available online: http://www.unesco.org/new/en/naturalsciences/environment/earth-sciences/unesco-global-geoparks/list-of-unesco-global-geoparks/ (accessed on 3 September 2019).

22. Brilha, J.; Gray, M.; Pereira, D.I.; Pereira, P. Geodiversity: An integrative review as a contribution to the sustainable development of the whole of nature. Environ. Sci. Policy 2018, 86, 19-28. [CrossRef]

23. Gray, M. Geodiversity. Valuing and Conserving Abiotic Nature; Wiley-Blackwell: Chichester, UK, 2013 ; pp. 1-495.

24. dos Santos, D.S.; Mansur, K.L.; de Arruda Jr, E.R.; Dantas, M.E.; Shinzato, E. Geodiversity Mapping and Relationship with Vegetation: A Regional-Scale Application in SE Brazil. Geoheritage 2019, 11, 399-415. [CrossRef]

25. Mikhailenko, A.V.; Ruban, D.A. Geoheritage in Deltaic Environments: Classification Notes, Case Example, and Geopark Implication. Environments 2019, 6, 18. [CrossRef] 
26. Semeniuk, C.A.; Semeniuk, V. Geoheritage values of consanguineous wetland suites on the Swan Coastal Plain, Western Australia. Aust. J. Earth Sci. 2019, 66, 837-853. [CrossRef]

27. Taha, M.M.N.; El-Asmar, H.M. Geo-Archeoheritage Sites Are at Risk, the Manzala Lagoon, NE Nile Delta Coast, Egypt. Geoheritage 2019, 11, 441-457. [CrossRef]

28. Fung, C.K.W.; Jim, C.Y. Segmentation by motivation of Hong Kong Global Geopark visitors in relation to sustainable nature-based tourism. Inter. J. Sustain. Dev. World Ecol. 2015, 22, 76-88.

29. Allan, M. Geotourism: Why do children visit geological tourism sites? Dirasat: Human Social. Sci. 2014, 41, 653-661. [CrossRef]

30. Chylinska, D. The Role of the Picturesque in Geotourism and Iconic Geotourist Landscapes. Geoheritage 2019, 11,531-543. [CrossRef]

31. Dowling, R.; Newsome, D. Handbook of Geotourism; Edward Elgar Publishing: Cheltenham, UK, 2018; pp. 1-499.

32. Hose, T.A. 3G's for Modern Geotourism. Geoheritage 2012, 4, 7-24. [CrossRef]

33. Macerinskiene, A. Determination criteria for national water tourism routes. WIT Trans. Ecol. Environ. 2010, 139, 145-158.

34. Omran, A.; Kamran, H.W. Determining the factors attracting the tourists to visit Kedah State, Malaysia. J. Environ. Manag. Tour. 2018, 9, 355-364. [CrossRef]

35. Sleszynski, P. Perception of visual attractiveness on the Pinczów vicinity. Przeglad Geograficzny 2001, 73, 371-386.

36. Simic, S.; Gavrilovic, B.; Živkovic, N.; Gavrilovic, L. Protection of Hydrological Heritage Sites of Serbia Problems and Perspectives. Geographica Pannonica 2012, 16, 84-93. [CrossRef]

37. Testa, B.; Aldighieri, B.; D’Alberto, L.; Lucianetti, G.; Mazza, R. Hydrogeology and Hydromorphology: a Proposal for a Dual-Key Approach to Assess the Geo-Hydrological Heritage Site of the San Lucano Valley (Belluno Dolomites, Italy). Geoheritage 2019, 11, 309-328. [CrossRef]

(C) 2019 by the author. Licensee MDPI, Basel, Switzerland. This article is an open access article distributed under the terms and conditions of the Creative Commons Attribution (CC BY) license (http://creativecommons.org/licenses/by/4.0/). 